\title{
Analisis Penerapan Tata Kelola Teknologi Informasi Menggunakan Cobit 4.1 Pada Peminjaman Buku Perpustakaan
}

\section{"Studi Kasus Perpustakaan Kabupaten Karawang"}

\author{
${ }^{1}$ Tukino, ${ }^{2}$ Faqih Pratama Muthi dan ${ }^{3}$ Aditia Agustian \\ 1,2,3 Sistem Informasi, FTIK, Universitas Buana Perjuangan Karawang \\ tukino@ubpkarawang.ac.id \\ si18.faqihmuhti@mhs.ubpkarawang.ac.id \\ si19.adittiaagustian@mhs.ubpkarawang.ac.id
}

\begin{abstract}
ABSTRAK
Perpustakaan Kab. Karawang dikelola oleh Dinas Arsip dan Dokumentasi Kabupaten Karawang. Dalam melaksanakan Tugas Pokok dan Tanggung Jawab perlu di dukung adanya Tata Kelola Teknologi Informasi yang memadai untuk menjamin sistem Informasi dapat digunakan dengan baik dan memberikan kemudahan bagi staf perpustakaan atau anggota perpustakaan. Untuk mengetahui kesiapan dalam menerapakan sistem informasi diperlukan Analisa Tata kelola Teknologi Informasi dengan menggunakan Cobit 4.1. Kerangka kerja Cobit 4.1 adalah kerangka kerja yan tepat untuk mengetahui tingkat kematangan tata kelola teknologi informasi. Tujuan dari penelitian ini adalah untuk mendapatkan hasil evaluasi berdasarkan tingkat kematangan dan menghasilkan rekomendasi untuk memperbaiki tata kelola teknologi informasi.

Berdasarkan hasil analisis tingkat kematangan dalam pengelolaan Tata Kelola Teknologi Informasi Dari Nilai Rata-rata maturity level dari Sistem Informasi Perpustakaan Kab Karawang adalah 2.84 berada pada level 3 (Defined). Untuk mencapai level $4: 3.50-4.49$ (Managed) sehinga masih terdapat kekurangan minimal sebesar 0.66 . Untuk memenuhi leve 4, perlu meningkatkan tata kelola yang baik.

Sedangkan Nilai maturity level terendah adalah DS4 seebsar 1.86, ini perlu ada usaha yang keras untuk mencapai level 3. Untuk nilai maturity level tertinggi adalah pada sistem layanan informasi Perpustakaan Kab Karawang pada Proses DS01 "Mendefinisikan dan mengelola tingkat layanan" adalah 4.18 berada pada level 4 (Managed) yaitu : $3.50-4.49$. Hasil maturity menunjukan bahwa pengukuran dan pemantaun terhadap kepatuhan dengan prosedur, serta pengambilan tindakan jika proses tidak berjalan secara efektif, dapat dilakukan perbaikan proses dilakukan secara konstan. Implementasi proses dilakukan secara baik. Otomasi dan perangkat yang digunakan terbatas.

Kata Kunci : Audit, Tata Kelola, Cobit 4.1 Maturity, Sistem Informasi
\end{abstract}




\begin{abstract}
District Library. Karawang is managed by the Karawang Regency Archives and Documentation Service. $n$ carrying out the Main Duties and Responsibilities, it is necessary to support the existence of adequate Information Technology Governance to ensure the information system can be used properly and provide convenience for library staff or library. To determine readiness in implementing information systems, it is necessary to analyze Information Technology Governance using COBIT 4.1. The Cobit 4.1 framework is an appropriate framework to determine the maturity level of information technology governance. The purpose of this study is to obtain evaluation results based on maturity levels and produce recommendations for improving information technology governance.

Based on the results of the analysis of the level of maturity in the management of Information $T$ echnology Governance, the average value of the maturity level of the Karawang Regency Library Information System is 2.84, which is at level 3 (Defined). To reach level 4: 3.50 - 4.49 (Managed) so that there is still a minimum deficiency of 0.66. To meet level 4, good governance is needed.

While the lowest maturity level value is DS4 of 1.86, this requires hard effort to reach level 3. For the highest level of maturity is the information service system of the Karawang District Library on the DSO1 Process "Defining and managing service levels" is 4.18 at level 4 (Managed), namely: 3.50 - 4.49. The results of maturity show that measurement and monitoring of compliance with procedures, as well as taking action if the process is not running effectively, can be carried out continuously. The process implementation is done well. Limited automation and devices used.
\end{abstract}

Keywords: Audit, Governance, Cobit 4.1 Maturity, Information Systems 


\section{PENDAHULUAN}

Penerapan Teknologi Informasi pada Perpustakaan Kabupaten Karawang untuk meningkatkan kinerja pelayanan yang mencakup kecepatan dalam mengakses informasi, keakuratan informasi, dan ketepatan dalam menyampaikan infromasi yang diperlukan oleh stakeholder. Untuk mengukur kinerja pelayanan perpustakaan dan mengidentifikasikan permasalahan dengan melakukan evaluasi penerapan Tata Kelola Teknologi Informasi. Perpustakaan Kabupaten Karawang adalah perpustakaan dikelola oleh Dinas Arsip dan Dokumentansi.

Berdasarkan hasil penelitian, diperoleh informasi bahwa pelayanan peminjaman buku telah dilengkapi dengan Standar Operasional Prosedur, Uraian tugas pegawai dan Pedoman Perpustakaan. Sedangakan Perencanaan Master Plan belum terintegrasi dengan perpustakaan lainnya yang ada di wilayah Karawang dan pengelolaan investasi masih belum sesuai dengan hasil yang didapatkan. Banyak kondisi yang masih harus dicapai dalam proses yang ada di domain Plan and Organise (PO) dan Acquire and Implement (AI).

Tujuan penelitian ini adalah mengevaluasi tingkat kesiapan penerapan Sistem Automasi Pelayanan Perpustakaan. Untuk memperoleh gambaran tentang penerapan Sistem Automasi pelayanan Perpustakaan dengan mengunakan Analisis Maturity Level, berdasarkan hasil analisis Maturity Level dihasilkan rekomendasi untuk memperbaiki Tata Kelola TI Perpustakaan Kabupaten Karawang. Audit tata Kelola Teknologi Informasi menggunakan framework COBIT 4.1 dan berfokus pada domain Plan and Organise (PO) dan Acquire and Implement (AI). COBIT (Control Objectives for Information and Related Technology) adalah framework tata kelola TI untuk mencapai kesenjangan antara masalah teknis, risiko bisnis dan kebutuhan control.

\section{METODOLOGI PENELITIAN}

\subsection{Metode Pengumpulan Data}

a. Survie

Penelitian diawali dengan melihat situasi dan kondisi di Perpustakaan Kabupaten Karawang pada saat jam buka dan pada saat proses kegiatan pelayanan. Dari hasil pengamatan atau kunjungan dipersipakan untuk menyusun formulir-formulir untuk mencari informasi dari informan. Setelah informasi terkumpul dilakukan pemetaan ke dalam cobit dan dilakukan analisa kematangan terhadap tata kelola teknologi informasi kemudian dibuatkan kesimpulan. 
b. Wawancara

Dilakukan dengan Kepala Perpustakaan, Kepala Bagian dan beberapa staf administrasi yang terkait dengan pelayanan Perpustakaan.

c. Kuesioner

Pengumpulan data dilakukan dengan penyebaran kuesioner kepada sampel pada populasi pada pegawai perpusakaan Kab Karawang sebanyak 8 orang pegawai, yaitu : 1) Kepala Perpustakaan (1 Orang), 2) Kepala Bidang Perpustakaan (1 Orang), 3) Pustakawan ( 1 Orang), 4) Bagian Pengguna/pengolahan ( 5 Orang). Penyebaran kuesioner ini dilakukan pada hari selasa, tanggal 8 Juni 2020, jumlah responden yang diberikan form kuesioner sebanyak 8 orang dan jumlah responden yang menyerahkan form kuesioner sebanyak 8 orang, hal ini menunjukkan bahwa partisipasi para pegawai perpustakaan dalam penelitian ini cukup bagus.

d. Studi Pustaka

Dilakukan dengan mencari referensi yang terkait dengan tema penelitian melalui buku, jurnal, internet dan sebagainya.

\subsection{Kerangka Kerja Cobit Metode Analisis}

COBIT (Control Objective for Information and Related Technology) merupakan a set of best practices (framework) bagi pengelolaan teknologi informasi (TI). COBIT disusun oleh The IT Governance Institute (ITGI) dan Information System Audit and Control Association (ISACA), tepatnya dulu disebut Information System Audit and Control Foundation (ISACF) pada tahun 1992. COBIT membantu memenuhi berbagai kebutuhan manajemen dengan menjembatani gap antara resiko bisnis, kebutuhan kendali dan permasalahan teknis. COBIT memberikan panduan melalui sebuah doman dan framework proses serta menyajikan aktivitas dalam sebuah struktur logis dan terkelola. Kaidah penerapan COBIT dibentuk dari konsensus para pakar yang akan membantu dalam mengoptimalkan investasi informasi dan akan memberikan sebuah ukuran ketika terdapat sebuah kesalahan. 
Aktivitas teknologi informasi pada COBIT 4.1 didefinisikan ke dalam empat domain yaitu Perencanaan dan Pengorganisasian / Plan and Organise (PO), Penyampaian Layanan dan Dukungan / Deliver and Support (DS), serta Pengadaan dan Implementasi / Acquire and Implement (AI), Monitor dan Evaluasi / Monitor and Evaluate (ME). Keempat domain tersebut saling berhubungan. PO menghasilkan arahan terhadap penyampaian solusi (AI) dan penyampaian layanan (DS). AI menghasilkan solusi dan membuatnya menjadi layanan. DS menerima solusi dan membuatnya dapat digunakan oleh user. ME memonitor semua proses untuk memastikan bahwa arahan yang ada telah dilaksanakan/diikuti. Gambar 3.2 menunjukan domain Cobot

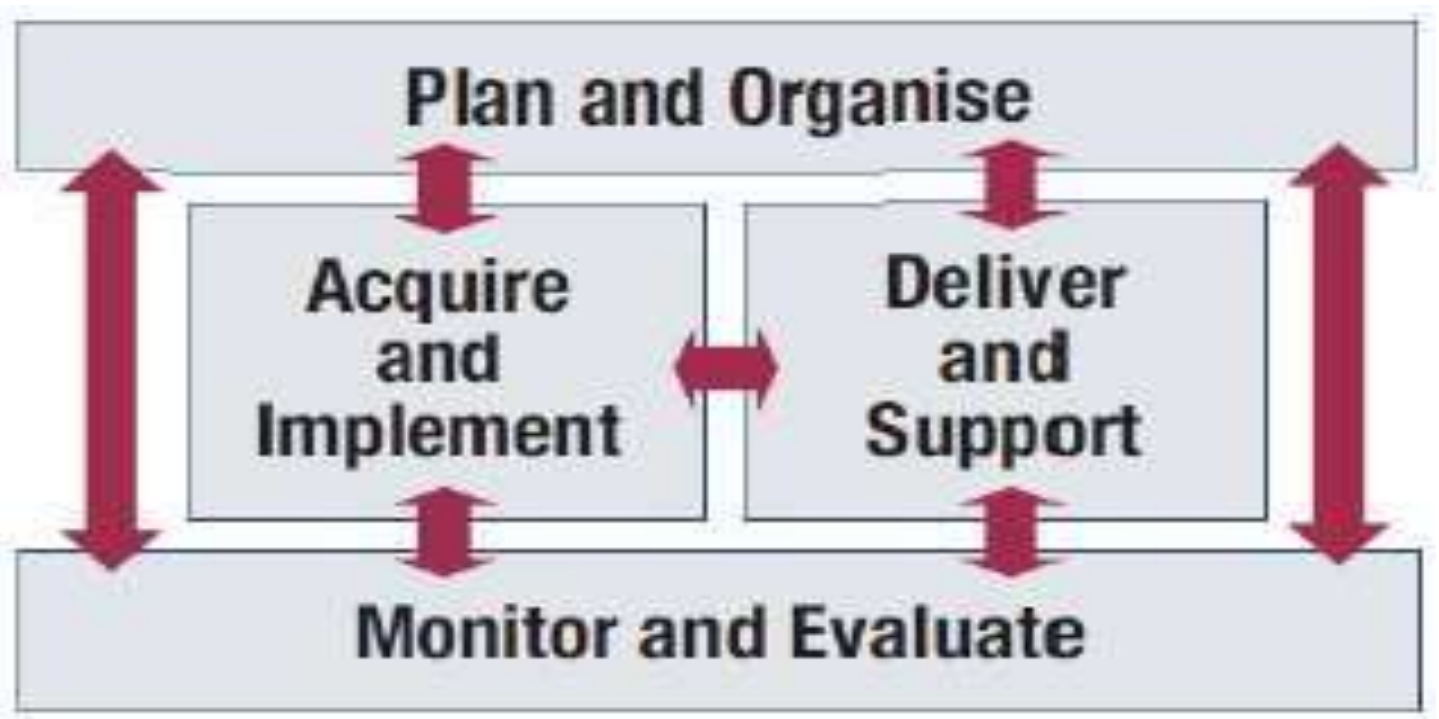

Proses TI yang diidentifikasi oleh COBIT, yang dipakai secara umum. Proses-proses ini dapat digunakan untuk memastikan kelengkapan aktifitas dan tanggung jawab, namun tidak semua proses harus diaplikasikan, dapat pula di kombinasikan, tergantung pada keperluan perusahaan. COBIT juga mendefinisikan sasaran kendali untuk setiap 34 proses tersebut. Sasaran kendali TI (IT control objective) merupakan sekumpulan pernyataan atau syarat yang menjadi pertimbangan oleh manajemen untuk mendapatkan kontrol yang efektif terhadap setiap proses TI. 


\subsection{Metode Analisis}

Salah satu alat pengukuran dari kinerja suatu sistem teknologi informasi adalah model kematangan (maturity level) dari COBIT. Model kematangan untuk pengelolaan dan pengendalian pada proses teknologi informasi didasarkan pada metode evaluasi organisasi sehingga dapat mengevaluasi sendiri dari level tidak ada (0) hingga optimis (5). Model kematangan dimaksudkan untuk mengetahui keberadaan persoalan yang ada dan bagaimana menentukan prioritas peningkatan. Pendefinisian model kematangan suatu proses teknologi informasi

1. Level 0: non-exixtent. Sama sekali tidak ada proses TI yang diidentifikasi. Perusahaan belum menyadari adanya isu yang akan dibahas

2. Level 1: initial/ad-hoc. Terdapat bukti yang memperlihatkan perusahaan telah menyadari adanya isu yang perlu dibahas. Tidak ada proses yang baku, sebagai gantinya ada pendekatan khusus yang cenderung diterapkan per kasus. Pendekatan manajemen secara keseluruhan belum terorganisasi.

3. Level 2: repeatable but intuitive. Proses telah berkembang pada tahap dimana prosedur serupa diikuti oleh orang berbeda yang melakukan tugas yang sama. Tidakada pelatihan dan komunikasi formal dari prosedur standar, dan tanggung jawab diserahkan kepada individu. Terdapat suatu kepercayaan yang tinggi terhadap pengetahuan dari individu, oleh karena itu kesalahan sering terjadi.

4. Level 3: defined process. Prosedur telah baku dan telah didokumentasikan, serta dikomunikasikan melalui pelatihan. Akan tetapi terserah kepada individu untuk mengikuti proses ini, oleh sebab itu penyimpangan akan sulit terdeteksi. Prosedur itu sendiri tidaklah rumit tetapi merupakan formalisasi dari kegiatan yang telah dilakukan.

5. Level 4: managed and measureable. Manajemen melakukan monitoring dan pengukuran kepatuhan terhadap prosedur dan pengambilan tindakan jika proses yang ada, nampak tidak bekerja secara efektif. Proses dikembangkan secara konstan dan memberikan good practice. Otomatisasi dan perangkat pembantu (tools) digunakan secara terbatas atau secara fragmentasi.

6. Level 5: optimized. Proses mencapai tingkatan bestpractice, sebagai hasil dari peningkatan terus-menerus dan maturity modeling dengan perusahaan lain. Teknologi informasi digunakan secara terintegrasi untuk mengotomatisasikan workflow, menyediakan 
perangkat pembantu untuk meningkatkan efektivitas dan mutu yang akan membuat perusahaan dapat dengan cepat menyesuaikan diri dengan perubahan.

Matriks untuk menunjukkan peran dan tanggung jawab tugas, atau yang disebut dengan RACI adalah matriks yang menjelaskan peran berbagai pihak yang ada untuk menyelesaikan pekerjaan dalam suatu proyek atau proses bisnis. RACI merupakan singkatan dari empat peran yaitu responsible, accountable, consulted dan informed (ITGI, 2007). Diagram RACI diterapkan di setiap aktivitas yang dijalankan pada pengendalian objektif TI. 


\section{HASIL DAN PEMBAHASAN}

Penerapan Teknologi Informasi Perpsutakaan Kab Karawang untuk mendukung pelayanan terhadap anggota perpustakaan, pengunjung perpustakaan, pihak Pemda Kab Karawang atau pihak internal perpustakaan sendiri yang terkait dengan penentu kenbijakan dan pelaksana pelayanan perpustakaan, maka dikembangkan Sistem Informasi Perpustakaan yang mencakup beberapa layanan yaitu layanan sistem katalog, layanan inventaris Buku, layanan keanggotaan dan layanan peminjaman dan pengembalian buku .Untuk mengukur kinerja dalam menerapkan sistem Informasi perpustakaan adalah dengan menggunakan model kematangan (Maturity level) Nilai maturity level secara keseluraham didapatkan dari pengidentifikasian dari tiap-tiap maturity level pada semua control objective yang terlibat.

\subsection{Pemetaan Business Goals COBIT}

Perpustakaan Kab Karawang mempunyai visi, misi dan tujuan. Untuk mencapai visi dan misi dirancang sasaran mutu dan program strategis yang dikerjakan setiap tahun. Dari dokumen tersebut dirangkum dalam bentuk Goal Bisnis atau Tujuan dan Sasaran Perpustakaan Kab. Karawang, yaitu :

1. Menyediakan bahan pustaka yang berkualitas

2. Meningkatkan layanan informasi perpustakaan kepada pengguna perpustakaan untuk dapat mengakses informasi secara lebih tepat.

3. Melestarikan dan mendayagunakan karya tulis untuk pengembangan ilmu pengetahuan.

4. Menciptakan dan membiasakan masyarakat gemar membca dan memanfaatkan informasi.

5. Menjadikan perpustakaan sebagi bahan rujukan/referensi

6. Terciptanya tata kelola organisasi dan sistem manajemen internal yang komitmen, konsisten, bertanggung jawab, profesional dan berdedikasi tinggi.

7. Meningkatnya kuantitas dan kualitas koleksi bahan pustaka. 
Berdasarkan Tujuan dan Sasaran Business Kab. Karawang, dilakukan pemetaan dengan sasaran dan tujuan business pada Cobit 4.1, sebagai berikut:

Tabel 4.1a. Business Goal COBIT.

\begin{tabular}{|c|c|c|}
\hline \multirow{3}{*}{$\begin{array}{l}\text { Financial } \\
\text { Perspectiv }\end{array}$} & 1 & Pengelolaan resiko bisnis yang terkait dengan TI \\
\hline & 2 & Peningkatan transparansi dan tata kelola organisasi \\
\hline & 3 & Penyediaan timbal balik investasi yang ditimbulkan oleh TI \\
\hline \multirow{6}{*}{$\begin{array}{l}\text { Customer } \\
\text { Perspective }\end{array}$} & 4 & Peningkatan layanan dan orientasi terhadap pelanggan \\
\hline & 5 & Penawaran produk dan jasa yang kompetitif \\
\hline & 6 & Penentuan ketersediaan dan kelancaran layanan \\
\hline & 7 & $\begin{array}{l}\text { Penciptaan ketangkasan untuk menjawab permintaan bisnis yang } \\
\text { berubah }\end{array}$ \\
\hline & 8 & Pencapaian optimasi biaya dari penyampaian layanan \\
\hline & 9 & $\begin{array}{l}\text { Perolehan informasi yang bermanfaat dan handal untuk pembuatan } \\
\text { keputusan strategis }\end{array}$ \\
\hline \multirow{6}{*}{$\begin{array}{l}\text { Internal } \\
\text { Perspective }\end{array}$} & 10 & Peningkatan dan pemeliharaan fungsionalitas proses bisnis \\
\hline & 11 & Penurunan biaya proses \\
\hline & 12 & Penyediaan kepatutan terhadap hukum eksternal, regulasi dan kontrak \\
\hline & 13 & Penyediaan kepatutan terhadap kebijakan internal \\
\hline & 14 & Pengelolaan perubahan bisnis \\
\hline & 15 & Peningkatan dan pengelolaan produktivitas operasional dan staf \\
\hline \multirow{2}{*}{$\begin{array}{l}\text { Learning and } \\
\text { growth } \\
\text { Perspective }\end{array}$} & 16 & Pengelolaan inovasi produk dan bisnis \\
\hline & 17 & $\begin{array}{l}\text { Perolehan dan pemeliharaan dan pemeliharaan karyawan yang cakap } \\
\text { dan termotivasi }\end{array}$ \\
\hline
\end{tabular}

Berdasarkan Business Goal Cobit 4.1 dan hasil identifikasi tujuan dan sasaran business Perpustakaan Kab, Karawang dilakukan pemetaan atau pencocokan, Adapun hasil pemetaan sebagai berikut :

Tabel 4.1b. Pemetaan Business Goal COBIT dengan Tujuan dan Sasaran Perpustakaan Pemda Karawang.

\begin{tabular}{|l|l|c|}
\hline No & \multicolumn{1}{|c|}{ Tujuan dan sasaran Perpustakaan } & $\begin{array}{c}\text { Nomor COBIT Business Goal } \\
\text { sesuai pada tabel 4.1a }\end{array}$ \\
\hline 1 & Menyediakan bahan pustaka berkualitas & $4,5,6,16$ \\
\hline 2 & $\begin{array}{l}\text { Meningkatkan layanan informasi perpiustakaan } \\
\text { kepada pengguna perpustakaan untuk dapat } \\
\text { mengakses informasi secara lebih tepat. }\end{array}$ & $4,6,7$ \\
\hline
\end{tabular}




\begin{tabular}{|l|l|c|}
\hline No & \multicolumn{1}{|c|}{ Tujuan dan sasaran Perpustakaan } & $\begin{array}{c}\text { Nomor COBIT Business Goal } \\
\text { sesuai pada tabel 4.1a }\end{array}$ \\
\hline 3 & $\begin{array}{l}\text { Melestarikan dan mendayagunakan karya tulis } \\
\text { untuk pengembangan ilmu pengetahuan. }\end{array}$ & $5,10,16$ \\
\hline 4 & $\begin{array}{l}\text { Menciptakan dan membiasakan masyarakat } \\
\text { gemar membca dan memanfaatkan informasi. }\end{array}$ & $5,9,15$ \\
\hline 5 & $\begin{array}{l}\text { Menjadikan perpustakaan sebagi bahan } \\
\text { rujukan/referensi }\end{array}$ & $13,15,17$ \\
\hline 6 & $\begin{array}{l}\text { Terciptanya tata kelola organisasi dan sistem } \\
\text { manajemen internal yang komitmen, konsisten, } \\
\text { bertanggung jawab, profesional dan berdedikasi } \\
\text { tinggi. }\end{array}$ & $\begin{array}{l}\text { Meningkatnya kuantitas dan kualitas koleksi } \\
\text { bahan pustaka. }\end{array}$ \\
\hline 7
\end{tabular}

Dari pemetaan diatas dihasilkan 10 item Business Goal COBIT yang digunakan yaitu :

1. Peningkatan layanan dan orientasi terhadap pelanggan (4)

2. Penawaran produk dan jasa yang kompetitif (5)

3. Penentuan ketersediaan dan kelancaran layanan (6)

4. Penciptaan ketangkasan untuk menjawab permintaan bisnis yang berubah (7)

5. Perolehan informasi yang bermanfaat dan handal untuk pembuatan keputusan strategis (9)

6. Peningkatan dan pemeliharaan fungsionalitas proses bisnis (10)

7. Penyediaan kepatutan terhadap kebijakan internal (13)

8. Peningkatan dan pengelolaan produktivitas operasional dan staf (15)

9. Pengelolaan inovasi produk dan bisnis (16)

10. Perolehan dan pemeliharaan dan pemeliharaan karyawan yang cakap dan termotivasi (17)

\subsection{Identifikasi IT Goals COBIT 4.1}

Pada tahap ini dilakukan identifikasi IT Goal pada Cobit 4.1 yang dicocokan dengan business goal perpustakaan yang terpilih sebagai berikut : 
Tabel 4.1c. IT goals yang terpilih.

\begin{tabular}{|c|c|}
\hline No & IT Goal \\
\hline 1 & $\begin{array}{l}\text { Respond to business requirements in alignment with the business strategy (Menanggapi } \\
\text { kebutuhan bisnis sejalan dengan strategi bisnis) }\end{array}$ \\
\hline 2 & $\begin{array}{l}\text { Ensure satisfaction of end users with service offerings and service levels (Memastikan kepuasan } \\
\text { pengguna terhadap layanan yang ditawarkan dan tingkat layanan) }\end{array}$ \\
\hline 3 & Optimise the use of information (Mengoptimalkan penggunaan informasi) \\
\hline 4 & Create IT agility (Menciptakan ketangguhan IT) \\
\hline 5 & $\begin{array}{l}\text { Define how business functional and control requirements are translated in effective and efficient } \\
\text { automated solutions (Mendefinisikan bagaimana fungsional bisnis dan kebutuhan kendali } \\
\text { dijalankan dalam solusi mandiri yang efektif dan efisien) }\end{array}$ \\
\hline 6 & $\begin{array}{l}\text { Acquire and mantain integrated and standardised application systems (Memperoleh dan } \\
\text { mengelola sistem aplikasi yang } \\
\text { terintegrasi dan terstandarisasi) }\end{array}$ \\
\hline 7 & $\begin{array}{l}\text { Acquire and mantain integrated and standardised IT infrastructure (Memperoleh dan mengelola } \\
\text { infrastruktur TI yang terintegrasi dan terstandarisasi) }\end{array}$ \\
\hline 8 & $\begin{array}{l}\text { Acquire and mantain IT skills that respond to the IT strategy (Memperoleh dan mengelola } \\
\text { keterampilan TI guna menanggapi strategi TI) }\end{array}$ \\
\hline 9 & $\begin{array}{l}\text { Ensure mutual satisfaction of third-party relationships (Memastikan kepuasan mutual dalam } \\
\text { hubungan dengan pihak ketiga) }\end{array}$ \\
\hline 10 & $\begin{array}{l}\text { Ensure seamless integration of application into business processes (Mengintegrasikan aplikasi } \\
\text { dan solusi teknologi kedalam proses bisnis tanpa henti) }\end{array}$ \\
\hline 11 & $\begin{array}{l}\text { Ensure proper use and performance of the applications into busines processes (Memastikan } \\
\text { penggunaan dan performa yang layak dari solusi teknologi dan aplikasi) }\end{array}$ \\
\hline 12 & $\begin{array}{l}\text { Optimise the IT infrastructure, resources and capabilities (Mengoptimalkan infrastruktur TI, } \\
\text { sumberdaya dan kemampuannya.) }\end{array}$ \\
\hline 13 & $\begin{array}{l}\text { Reduce solution and service delivery defects and rework (Mengurangi cacat dan pengerjaan } \\
\text { ulang dari penyampaian layanan dan solusi) }\end{array}$ \\
\hline 14 & $\begin{array}{l}\text { Estabilish clarity of business impact of risk to IT objectives and resources (Memastikan kejelasan } \\
\text { pengaruh bisnis dari resiko terhadap tujuan dan sumbedaya TI) }\end{array}$ \\
\hline 15 & $\begin{array}{l}\text { Ensure that critical and confidential information is withheld from those who should not have } \\
\text { access to it (Memastikan informasi yang penting dan rahasia aman dari pihak yang tidak } \\
\text { seharusnya mengakses) }\end{array}$ \\
\hline 16 & $\begin{array}{l}\text { Ensure that automated business transaction and information exchanges can be trusted } \\
\text { (Memastikan bahwa transaksi terotomatisasi dan perpindahan data dapat dipercaya) }\end{array}$ \\
\hline 17 & $\begin{array}{l}\text { Ensure that IT services and infrastructure can properly resist and recover from failures due to } \\
\text { error, deliberate attack or disaster (Memastikan layanan TI dan infrastruktur TI dapat tahan dan } \\
\text { pulih dari kegagalan yang disebabkan oleh kesalahan, serangan yang disengaja maupun bencana } \\
\text { alam) }\end{array}$ \\
\hline 18 & $\begin{array}{l}\text { Ensure minimum business impact in the event of an IT service distruption or change } \\
\text { (Memastikan pengaruh minimal terhadap bisnis saat terjadi gangguan layanan TI atau perubahan } \\
\text { TI) }\end{array}$ \\
\hline
\end{tabular}




\begin{tabular}{|c|l|}
\hline No & \multicolumn{1}{|c|}{ IT Goal } \\
\hline 19 & $\begin{array}{l}\text { Make sure that IT services are available as required (Memastikan bahwa layanan TI tersedia } \\
\text { sebagaimana dibutuhkan/diminta) }\end{array}$ \\
\hline 20 & $\begin{array}{l}\text { Improve IT's cost-efficiency and its contribution to business profitability (Meningkatkan } \\
\text { efesiensi biaya TI dan kontribusinya terhadap keuntungan bisnis) }\end{array}$ \\
\hline 21 & $\begin{array}{l}\text { Deliver project on time and on budget, meeting quality standards (Menyampaikan proyek tepat } \\
\text { waktu dan tepat anggaran, sesuai standar mutu) }\end{array}$ \\
\hline 22 & $\begin{array}{l}\text { Maintain the integrity of information and processing infrastructure (Mengelola integritas } \\
\text { informasi dan infrastruktur proses) }\end{array}$ \\
\hline 23 & $\begin{array}{l}\text { Ensure IT compliance with laws, regulations and contracts (Memastikan kepatuhan TI terhadap } \\
\text { hukum, regulasi dan perjanjian) }\end{array}$ \\
\hline 24 & $\begin{array}{l}\text { Ensure that IT demonstrates cost-rfficient service quality, contimous improvement and readlines } \\
\text { for future change (Memastikan bahwa TI menampilkan kualitas layanan yang efisien-biaya, } \\
\text { peningkatan berkelanjutan dan kesiapan untuk perubahan masa depan) }\end{array}$ \\
\hline
\end{tabular}

\subsection{Identifikasi IT Process COBIT 4.1}

Pada tahap ini ditentukan IT Proses yang mempunyai kesesuaian dengan IT goals untuk menunjang busniness goal perpustakaan. Pada Tabel 4.1d adalah IT Proces yang terpilih.

\begin{tabular}{|l|l|l|}
\hline No & \multicolumn{2}{|c|}{ IT Process } \\
\hline 1 & P04 & $\begin{array}{l}\text { Define the IT processes, organisation and relationships (Mendefinisikan } \\
\text { prosesproses TI, organisasi dan hubungan) }\end{array}$ \\
\hline 2 & PO5 & $\begin{array}{l}\text { Manage the IT investment (Mengelola investasi TI) } \\
\text { Communicate management aims and direction (Mengkomunikasikan tujuan dan } \\
\text { arahan manajemen) }\end{array}$ \\
\hline 4 & PO6 & Mengelola sumberdaya manusia Teknologi Informasi \\
\hline 5 & PO8 & Manage quality (Mengelola kualitas) \\
\hline 6 & PO10 & Manage projects (Mengelola Proyek) \\
\hline 7 & AI3 & $\begin{array}{l}\text { Acquire and maintain technology infrastructure (Memperoleh dan memelihara } \\
\text { infrastruktur teknologi) }\end{array}$ \\
\hline 8 & AI4 & Enable operation and use (Memungkinkan pengoprasian dan penggunaan) \\
\hline 9 & AI5 & Memperoleh/mendapatkan sumberdaya Teknologi Informasi \\
\hline 10 & AI6 & Manage changes (Mengelola perubahan) \\
\hline 11 & AI7 & $\begin{array}{l}\text { Install and accredit solutions and changes (Menerapkan dan mengakui solusi dan } \\
\text { perubahan) }\end{array}$ \\
\hline 12 & DS1 & Define and manage service levels (Mendefinisikan dan mengelola tingkat layanan) \\
\hline 13 & DS3 & Mengelola kinerja dan kapasitas \\
\hline 14 & DS4 & Ensure continuous service (Memastikan layanan yang terusmenerus) \\
\hline 15 & DS7 & Educate and train users (Mendidik dan melatih pengguna) \\
\hline 16 & DS8 & Manage service desk and incidents (Mengelola bagian pelayanan dan insiden) \\
\hline 17 & DS10 & Manage problems (Mengelola masalah) \\
\hline 18 & DS13 & Manage operations (Mengelola operasi) \\
\hline & &
\end{tabular}




\begin{tabular}{|l|l|l|}
\hline No & \multicolumn{2}{|c|}{ IT Process } \\
\hline 19 & ME1 & Monitor and evaluate IT performance (Mengawasi dan mengevaluasi kinerja TI) \\
\hline 20 & ME4 & Provide IT governance (Mengadakan tata kelola TI) \\
\hline
\end{tabular}

\subsection{Klasifikasi Proses TI COBIT 4.1}

Narasumber yang dipilih untuk mengisi kuesioner ditentukan berdasarkan peran yang telah ditentukan dalam Cobit 4. denagn merujuk pada RACI (Responsible, Accountable, Consulted and/or Informed) pada setiap proses TI. Hasil pemetaan setiap IT Proses dengan narasumber secara spesifik dengan mengacu pada tanggun jawab yang dipetakan pada diagram RACI COBIT

4.1. sebagai berikut

\begin{tabular}{|c|c|c|c|c|c|c|c|c|c|c|}
\hline \multirow[t]{2}{*}{ NO } & \multirow[t]{2}{*}{ Kode } & \multirow[t]{2}{*}{ IT Proses } & \multicolumn{8}{|c|}{ Responden } \\
\hline & & & 1 & 2 & 3 & 4 & 5 & 6 & 7 & 8 \\
\hline 1 & P04 & $\begin{array}{l}\text { Mendefinisikan proses proses Teknologi Informasi, } \\
\text { organisasi dan hubungan }\end{array}$ & * & $*$ & & & & & & \\
\hline 2 & PO5 & Mengelola investasi Teknologi Informasi & $*$ & $*$ & & & & & & \\
\hline 3 & PO6 & Mengkomunikasikan tujuan dan arahan manajemen & $*$ & $*$ & & & & & & \\
\hline 4 & PO7 & $\begin{array}{llll}\text { Mengelola } & \text { sumberdaya } & \text { manusia } & \text { Teknologi } \\
\text { Informasi } & & & \end{array}$ & * & $*$ & & & & & & \\
\hline 5 & PO8 & Mengelola kualitas & $*$ & $*$ & $*$ & * & $*$ & $*$ & $*$ & * \\
\hline 6 & PO10 & Mengelola Proyek/kebutuhan sistem perpustakaan & $*$ & & $*$ & $*$ & $*$ & $*$ & $*$ & $*$ \\
\hline 7 & $\mathrm{AI} 3$ & $\begin{array}{l}\text { Memperoleh dan memelihara infrastruktur } \\
\text { teknologi }\end{array}$ & $*$ & & $*$ & & & & & \\
\hline 8 & AI4 & Memungkinkan pengoprasian dan penggunaan & * & & * & * & * & * & * & * \\
\hline 9 & AI5 & $\begin{array}{l}\text { Memperoleh/mendapatkan sumberdaya Teknologi } \\
\text { Informasi }\end{array}$ & $*$ & $*$ & & & & & & \\
\hline 10 & AI6 & Mengelola perubahan & $*$ & & * & $*$ & $*$ & $*$ & $*$ & * \\
\hline 11 & AI7 & Menerapkan dan mengakui solusi dan perubahan & * & $*$ & $*$ & * & $*$ & $*$ & * & $*$ \\
\hline 12 & DS1 & Mendefinisikan dan mengelola tingkat layanan & $*$ & $*$ & & * & $*$ & * & $*$ & * \\
\hline 13 & DS3 & Mengelola kinerja dan kapasitas & $*$ & $*$ & $*$ & & & & & \\
\hline 14 & DS4 & Memastikan layanan yang terus menerus & $*$ & & $*$ & * & $*$ & $*$ & $*$ & $*$ \\
\hline
\end{tabular}




\begin{tabular}{|c|c|c|c|c|c|c|c|c|c|c|}
\hline \multirow[t]{2}{*}{ NO } & \multirow[t]{2}{*}{ Kode } & \multirow[t]{2}{*}{ IT Proses } & \multicolumn{8}{|c|}{ Responden } \\
\hline & & & 1 & 2 & 3 & 4 & 5 & 6 & 7 & 8 \\
\hline 15 & DS7 & Mendidik dan melatih pengguna & * & & & & & & & \\
\hline 16 & DS8 & Mengelola bagian pelayanan dan insiden & $*$ & & & $*$ & * & * & $*$ & * \\
\hline 17 & DS10 & Mengelola masalah & $*$ & & $*$ & $*$ & $*$ & $*$ & * & * \\
\hline 18 & DS13 & Mengelola operasi & * & & & $*$ & * & $*$ & $*$ & * \\
\hline 19 & ME1 & $\begin{array}{l}\text { Mengawasi dan mengevaluasi kinerja Teknologi } \\
\text { Informasi }\end{array}$ & $*$ & $*$ & & & & & & \\
\hline 20 & ME4 & Mengadakan tata kelola Teknologi Informasi & * & * & & & & & & \\
\hline
\end{tabular}

a. Penilaian Kuesioner

Penilaian skor (nilai) yang berikan reponden dalam mengisi kuesioner menggunakan skala Likert yang merefleksikan pola jawaban 1=Tidak Sesuai, 2=Kurang Sesuai, 3=Sesuai, dan 4=Sangat Sesuai. Selanjutnya data yang terkumpul melalui penyebaran kuesioner digunakan untuk mengukur tingkat kematangan atau maturity level Perpustakaan Kab Karawang. Dari masingmasing kriteria dalam kuesioner memiliki nilai indeks,yang diukur dengan menggunakan rumus sebagai berikut :

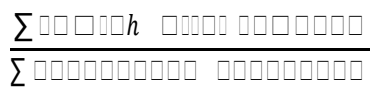

Skala pembuatan indeks memiliki pemetaan ketingkatan maturity model yang dilakukan oleh Djatmika terdapat 6 tingkat yaitu :

\begin{tabular}{|l|l|l|l|}
\hline No & \multicolumn{1}{|c|}{ Indeks } & \multicolumn{1}{|c|}{ Tingkat } & \multicolumn{1}{|c|}{ Artinya } \\
\hline 1 & $0.00-0.49$ & $\begin{array}{l}\text { 0 (Non-Existen t) } \\
\text { Tidak ada, }\end{array}$ & $\begin{array}{l}\text { kurang lengkapnya setiap proses yang dikenal. } \\
\text { Organisasi sama sekali tidak mengetahui adanya } \\
\text { masalah. }\end{array}$ \\
\hline 2 & $0.50-1.49$ & $\begin{array}{l}\text { 1(Initial/Ad Hoc) } \\
\text { Inisialisasi, }\end{array}$ & $\begin{array}{l}\text { terdapat bukti bahwa organisasi telah mengetahui } \\
\text { adanya masalah yang membutuhkan penanganan. } \\
\text { Penanganan masalah dilakukan dengan pendekatan } \\
\text { adhoc, beradasarkan kasus dari perorangan. Tidak }\end{array}$ \\
\hline
\end{tabular}




\begin{tabular}{|c|c|c|c|}
\hline No & Indeks & Tingkat & Artinya \\
\hline & & & $\begin{array}{l}\text { dilakukannya pengelolaan proses yang teroganisir. } \\
\text { Setiap proses ditangani tanpa menggunakan standar. }\end{array}$ \\
\hline 3 & $1.50-2.49$ & $\begin{array}{l}2 \quad \text { (Repeatable) } \\
\text { Pengulangan, }\end{array}$ & $\begin{array}{l}\text { Prosedur yang sama telah dikembangkan dalam proses } \\
\text { - proses untuk menangani suatu tugas, dan diikuti oleh } \\
\text { setiap orang yang telibat didalamnya. Tidak ada } \\
\text { pelatihan dan komunikasi dari prosedur standarc } \\
\text { tersebut. Tanggung jawab pelaksanaan individu sangat } \\
\text { tinggi, sehingga kesalahan sangat memungkinkan } \\
\text { terjadi. }\end{array}$ \\
\hline 4 & $2.50-3.49$ & $\begin{array}{l}3 \text { (Defined) } \\
\text { Terdefinisi, }\end{array}$ & $\begin{array}{l}\text { prosedur telah distandardisasikan, didokumentasikan, } \\
\text { serta dikomunikasikan melalui pelatihan. Namun, } \\
\text { implementasinya diserahkan pada setiap individu, } \\
\text { sehingga kemungkinan besar penyimpangan tidak } \\
\text { dapat dideteksi. Prosedur tersebut dikembangkan } \\
\text { sebagai bentuk formulasi dari praktik yang ada. }\end{array}$ \\
\hline 5 & $3.50-4.49$ & $\begin{array}{l}4 \text { (Managed) } \\
\text { Dikelola, }\end{array}$ & $\begin{array}{l}\text { pengukuran dan pemantaun terhadap kepatuhan } \\
\text { dengan prosedur, serta pengambilan tindakan jika } \\
\text { proses tidak berjalan secara efektif, dapat dilakukan } \\
\text { Perbaikan proses dilakukan secara konstan } \\
\text { Implementasi proses dilakukan secara baik. Otomas } \\
\text { dan perangkat yang digunakan terbatas. }\end{array}$ \\
\hline 6 & $4.50-5.00$ & $\begin{array}{l}5 \quad \text { (Optimised) } \\
\text { Dioptimalkan, }\end{array}$ & $\begin{array}{l}\text { implementasi proses dilakukan secara memuaskan. Ha } \\
\text { tersebut merupakan hasil dari perbaikan proses yang } \\
\text { terus menerus dan pengukuran tingkat kedewasaan } \\
\text { organisasi. Teknologi informasi diintegrasikan dengan } \\
\text { aliran kerja, dan berfungsi sebagai perangkat yang } \\
\text { memperbaiki kualitas dan efektifitas. Organisasi lebih } \\
\text { renponsive dalam menghadapi kompetisi bisnis. }\end{array}$ \\
\hline
\end{tabular}

\section{b. Perhitungan Keusioner}

Hasil Tabulasi diperoleh nilai setiap pertanyaan dan dijumlahkan setiap level objective, kemudian dicari nilai indeks dari setiap proses domain yang telah dikelola. Tabel 4.7 ini menunjukan nilai indeks setiap level objectives

\begin{tabular}{|l|c|c|}
\hline No & Proses & Indeks \\
\hline 1 & P04 & 2.58 \\
\hline 2 & PO5 & 2.25 \\
\hline
\end{tabular}




\begin{tabular}{|c|c|c|}
\hline No & Proses & Indeks \\
\hline 3 & PO6 & 3.69 \\
\hline 4 & PO7 & 3.3 .7 \\
\hline 5 & PO8 & 3.26 \\
\hline 6 & PO10 & 3.07 \\
\hline 7 & AI3 & 2.86 \\
\hline 8 & AI4 & 2.75 \\
\hline 9 & AI5 & 2.81 \\
\hline 10 & AI6 & 2.83 \\
\hline 11 & AI7 & 3.27 \\
\hline 12 & DS1 & 4.18 \\
\hline 13 & DS3 & 3.25 \\
\hline 14 & DS4 & 1.84 \\
\hline 15 & DS7 & 3.13 \\
\hline 16 & DS8 & 3.10 \\
\hline 17 & DS10 & 3.03 \\
\hline 18 & DS13 & 3.06 \\
\hline 19 & ME1 & 2.86 \\
\hline 20 & ME4 & 3 \\
\hline \multicolumn{2}{|r|}{ Total } & 56.82 \\
\hline \multicolumn{2}{|r|}{ Rata-Rata } & 2.84 \\
\hline
\end{tabular}

E ISSN : 2580-5517 
Berdasarkan hasil analisis tingkat kematangan dalam pengelolaan Tata Kelola Teknologi Informasi Dari Nilai Rata-rata maturity level dari Sistem Informasi Perpustakaan Kab Karawang adalah 2.84 berada pada level 3 (Defined). Untuk mencapai level $4: 3.50$ - 4.49 (Managed) sehinga masih terdapat kekurangan minimal seebsar 0.66. Untuk memenuhi leve 4, perlu meningkatkan tata kelola yang baik.

Sedangkan Nilai maturity level terendah adalah DS4 seebsar 1.86, ini perlu ada usaha yang keras untuk mencapai level 3. Untuk nilai maturity level tertinggi adalah pada sistem layanan informasi Perpustakaan Kab Karawang pada Proses DS01 "Mendefinisikan dan mengelola tingkat layanan" adalah 4.18 berada pada level 4 (Managed) yaitu : $3.50-4.49$. Hasil maturity menunjukan bahwa pengukuran dan pemantaun terhadap kepatuhan dengan prosedur, serta pengambilan tindakan jika proses tidak berjalan secara efektif, dapat dilakukan perbaikan proses dilakukan secara konstan. Implementasi proses dilakukan secara baik. Otomasi dan perangkat yang digunakan terbatas.

\section{DAFTAR PUSTAKA}

[1] Arikunto, Suharsimi. 2006. Prosedur Penelitian Suatu Pendekatan Praktik. Rineka Cipta, Jakarta.

[2] Gondodiyoto, Sanyoto. 2007.Audit Sistem Informasi Pendekatan Cobit (Edisi Revisi). Mitra Wacana Media, Jakarta.

[3] IT Governance Institute/ITGI. 2007. Framework, Control Objectives, Management Guidelines, Maturity Models, COBIT Version 4.1. IT Governance Institute, Illinois.

[4] Jogiyanto. 2001. Analisa dan Desain Sistem Informasi Pendekatan Terstruktur Teori Dan Praktek Aplikasi Bisnis. Andi, Yogyakarta.

[5] Nazir. 2014. Metodologi Penelitian, Ghalia Indonesia, Bogor

[6 ] Kenneth C.Loudon. Jane Price Loudon (2006), , Management Information System. Reason Hill.

[7] Roger Presman, PhD (2010), Rekayasa Perangkat Lunak, MCGraw-Hill

[8] Surendro, Kridanto. 2009. Implementasi Tata Kelola Teknologi Informasi. Informatika, Bandung

[9] Arumana, Arini. 2014. Analisis Tata Kelola Teknologi Informasi Menggunakan Kerangka Kerja COBIT 4.1 Pada Fakultas Teknik UNDIP. Jurnal Teknologi dan Sistem Komputer Fakultas Teknik Universitas Diponegoro.

[10] Lusiana, Dewi. 2017. Mengevaluasi Tingkat Kematangan Domain Delivery 
[11]Support (DS11) Perpustakaan Menggunakan Kerangka COBIT 4.1.Jurnal Sistem \& Teknologi Informasi Indonesia Jurusan Teknik Informatika Fakultas Teknik Universitas Muhammadiyah Jember.

[12] Riyani, Ade Riri. 2015. Analisis Tingkat Kematangan Proses Digitalisasi Koleksi Buku Langka Perpustakaan Nasional RI Menggunakan COBIT 4.1. Tesis Program Studi Teknologi Informasi untuk Perpustakaan Insitut Pertanian Bogor. 